\title{
ІСТОРІОГРАФІЯ ВИНИКНЕННЯ ТА РОЗВИТКУ МЕНЕДЖМЕНТУ МУЗИЧНОЇ КУЛЬТУРИ В НАУКОВО-ТЕОРЕТИЧНИХ ПРОЄКЦІЯХ
}

Обух Л. В.

\section{ВСТУП}

Історія розвитку менеджменту як науки про організацію та управління відносно нова і сягає початку XX-го століття, хоча потреба в такій науці 3'явилась дещо раніше, наприкінці XIX-го століття, і була пов'язана 3 появою та швидким розвитком машинного виробництва. Якщо на початку XX-го ст. зародження і становлення наукового менеджменту пов'язане із утвердженням світових економічних моделей, то сучасний етап розвитку менеджменту як науки (від 1940-х рp. і продовжується дотепер) вирізняє провідні наукові теоретичні підходи (процесний, системний, ситуаційний), які дозволяють узагальнити закономірності та принципи управління i менеджменту, а також виявити загальні тенденції- універсалізм, організаційну культуру, конкурентноспроможність як мистецтво будь-якої організаційної та управлінської діяльності. Серед найбільш визнаних у світі сучасних теоретиків менеджменту - П. Друкер, М. Портер, Б. Гейтс, Ф. Котлер, Г. Мінцберг та ін.

Менеджмент XXI століття став самостійним культурним утворенням 3 певними цінностями, нормами, традиціями, певною субкультурою тощо. Фірмовий стиль, імідж, організаційна культура, корпоративний командний дух як складники сучасної парадигми управління уособлюють новий концепт управлінської діяльності будь-якою справою.

Відбір кращих досягнень менеджменту на усіх етапах його становлення в нових умовах соціально-економічних реалій дозволив сформувати та продовжує розвивати низку його найефективніших складників (стратегічний менеджмент, маркетинг, технологія «паблік рілейшнз» тощо) і для культурно-мистецької сфери, зокрема музичної культури.

Накопичення та збагачення відповідних загальних знань і вмінь дало поштовх до формування у другій половині ХХ-го століття спеціалізованих теоретичних дисциплін, у тому числі й мистецького спрямування.

Становлення та розвиток менеджменту музичної культури - досі не звідана сторінка в українській культурології, що й спонукало нас до теоретичних узагальнень та складає ціль пропонованої розвідки. 


\section{1. Історія розвитку менеджменту музичної культури як науки в світовому соціокультурному просторі}

3 наукових позицій питання менеджменту культури порушив у 1967 p. американець Ф. Котлер, вперше звернувши увагу в одній зі своїх праць на те, що організації у сфері культури (наприклад, концертні зали чи університети) також $є$ виробниками культурної продукції. Перші дослідження 3 менеджменту в сфері культури (Ф. Котлер, А. Райс, М. Моква, Дж. Меліло, К. Діглс, Е. Хіршман, Ф. Кольбер) з'явились у західному суспільстві наприкінці 1960-х - початку 1970-х років. Основоположники PR-менеджменту C. Блек ${ }^{1}$, M. Маклюен ${ }^{2}$, C. Катліп ${ }^{3}$ доповнили формування уявлень про особливості використання технологій менеджменту та можливості їх ефективного застосування у соціально-гуманітарній сфері.

У межах курсу менеджменту, що активно розроблявся та впроваджувався в систему західної вищої освіти, з'явилась ще одна дисципліна галузі підприємницької діяльності - маркетинг, зумовлена пошуком нових методів реалізації товарів. Економічно розвинуті країни почали використовувати ринкову концепцію управління або маркетинг як систему організації та управління виробничо-збутовою i торгівельною діяльністю, орієнтованою на досягнення ринкового успіху організацій. Ї̈̈ розробники Ф. Кольбер ${ }^{4}$, Ф. Котлер ${ }^{5}$, М. Портер 6 відображали принципово нове бачення проблематики управління. Зокрема, Ф. Котлер, розглядаючи переважно управлінські аспекти, трактував маркетинг як універсальну форму діяльності, властиву не тільки комерційним, а й усім іншим організаціям ${ }^{7}$.

Маркетинг у сфері культури та мистецтв досить грунтовно почали розробляти в Канаді у другій половині XX століття (цей процес триває донині), виходячи з потреби підготовки в країні професійних менеджерів мистецтв. Одними $з$ перших у 1984 році до цього питання звернулася Канадська асоціація викладачів управління мистецькими організаціями (CAAAE) i, як наслідок, у 1987 році опублікувала «Підсумковий звіт про потреби підготовки менеджменту неприбуткових мистецьких та історико-культурних організацій, фінансованих урядом Канади». Для

\footnotetext{
${ }^{1}$ Блэк С. Паблик рилейшнз: Что это такое?: пер. с. англ. Москва : Модино Пресс, 1990. 239 с.

${ }_{2}^{2}$ Маклюэн М. Понимание медиа: внешние расширения человека: пер. с англ. Москва : Кучково поле, 2007. $464 \mathrm{c}$.

Катлип С., Сентер Д., Брум Г. Паблик рилейшенз. Теория и практика, 8-е изд. : пер. с англ. : уч. пос. Москва : Издательский дом «Вильямс», 2003. 624 с. : ил.

${ }^{4}$ Кольбер Ф., Нантель Ж., Білодо С., Річ Дж. Д. Маркетинг у сфері культури та мистецтв : пер. 3 англ. Яринича С., за наук. ред. Безгіна І. Львів : «Кальварія», 2004. С. 28-29.

Kotler P. Marketing Managament: Analysis, Planning and Control. Englewood Cliffs, New Jersey : Prentice-Hall, 1967. 628 p.

${ }^{6}$ Портер М. Международная конкуренция: пер. с англ. Москва : Междунар. отношения, 1993. $896 \mathrm{c}$.

${ }^{7}$ Хміль Ф.І. Основи менеджменту : підручник. Вид. 2-ге, випр., доп. Київ : Академвидав, 2007. C. 107.
} 
задоволення такої потреби у 1994 році Ф. Кольбер видав канадський підручник для менеджерів культурної сфери «Маркетинг у сфері культури та мистецтв». Доповнене й оновлене видання підручника ${ }^{8}$ 3'явилось у 2001 році як наслідок всесвітнього поширення програм 3 мистецького менеджменту та активної діяльності Міжнародної асоціації культурно-мистецького менеджменту (АIMAC - дослідницька мережа, діяльність якої спрямована на проведення кожні два роки конференцій $з$ менеджменту та споживання у сфері культури). Окрім того, у 1998 році $\Phi$. Кольбер став редактором неприбуткового наукового часопису "International Journal of Arts Management"9 Монреальського університету та AIMAC, де публікуються дослідження конкретної менеджерської діяльності культурно-мистецьких організацій ${ }^{10}$. Цей спеціалізований журнал до сьогодні в американській періодиці продовжує висвітлювати теоретичні питання менеджменту мистецтв. Перший номер журналу побачив світ восени 1998-го року у м. Монреаль провінції Квебек (Канада) та швидко завоював високі читацькі рейтинги наукової спільноти, зокрема завдяки публікаціям вищеназваних авторів. Кожен випуск журналу має близько 80-ти сторінок і охоплює широкий спектр тем та поглядів, що безпосередньо цікавлять науковців та практиків у галузі менеджменту мистецтв.

Підприємницький стиль у сфері мистецтва від початку 1990-х років досліджує нідерландець Г. Гагоорт. Його книга «Підприємництво в культурі, вступ до менеджменту мистецтва» (перша у цьому напрямі не лише в європейському контексті, а й у світовому) публікується різномовними версіями у 1992-му, 1993-му та 1995 -му роках ${ }^{11}$. Автор також $є$ ініціатором створення першої унікальної магістерської програми «Менеджмент мистецтва в європейському контексті» в Утрехтській школі мистецтв (Нідерланди, 1998), курс лекцій до якої став основою навчального посібника «Менеджмент мистецтва. Підприємницький стиль» $(2000)^{12}$. Предметно питання саме музичного менеджменту вперше порушив співзасновник комп'ютерної системи "Microsoft", американський бізнесмен і філантроп П.Г. Аллен у праці «Мистецький менеджмент для музичного бізнесу» $(2007)^{13}$.

Глобалізаційний світовий процес зумовив активне впровадження у мистецьку сферу інноваційних форм і технологій менеджменту. На

\footnotetext{
${ }^{8}$ Colbert F, Bilodeau S., Rich J. D. Marketing culture and the arts. $2^{\text {sd }}$ ed. Montreal: Presses HEC, 2001. (1 ${ }^{\text {st }}$ ed. 1994).

9 International Journal of Arts Management. https://www.facebook.com/pages/category/Organization/ International-Journal-of-Arts-Management-179737708761574/ (дата звернення: 01.02.2020).

${ }^{10}$ Кольбер Ф., Нантель Ж., Білодо С., Річ Дж. Д. Маркетинг у сфері культури та мистецтв : пер. 3 англ. Яринича С., за наук. ред. Безгіна І. Львів : «Кальварія», 2004. С. 7-8.

11 Гагоорт Г. Менеджмент мистецтва. Підприємницький стиль / переклав 3 англійської Б. Шумилович. Львів : Літопис, 2008. С. 15.

${ }^{12}$ Там же. С. 13.

${ }^{13}$ Allen P. Artist Managament for the Music Business. USA : Published by Elsevier Inc., 2007. 298 p.
} 
сучасному етапі однією з таких форм виявилась міжнародна цифрова платформа Art Managemant Network як мережа управління мистецтвом $\left(\right.$ State of the Arts) ${ }^{14}$. Цей інформаційний сайт створено в Америці для менеджерів, дослідників, студентів, політиків, журналістів та митцівпрофесіоналів у галузі культури і мистецтв по всьому світу (з відкритим доступом у соціальних мережах Twitter, Facebook, Youtube). Задекларована мета створення платформи - висвітлення нових підходів та моделей в управлінні мистецтвом у контексті глобальних розробок 3 особливим фокусуванням на східні країни, де пропонують різні послуги, такі як: щомісячний інформаційний бюлетень, цифровий журнал "Arts Management Quarterly", календар подій та конференцій або посібник з курсів управління академічним мистецтвом в усьому світі. Організаторам мистецьких конференцій, курсів, бізнес-установ тощо пропонується використовувати створений сайт для реклами власних програм чи продуктів, а також для пошуку медіа-партнерств. Мережа продукує різні форми співпраці з асоціаціями та установами, а також медіа-партнерства 3 організаторами мистецьких заходів, надаючи супровідний звіт до, під час та після події.

Кінець XX-го - початок XXI-го століть ознаменувався значним інтересом пострадянських країн до основ менеджменту та маркетингу як управлінських економічних технологій, доступ до яких обмежувався провладною системою впродовж існування Радянського Союзу.

Серед розробників курсу менеджменту в галузі культури та мистецтв на пострадянських просторах першими виокремлюються російські науковці та митці, серед яких плеяда культурологів і музикознавців: Т. Воротной, С. Коленько, С. Корнєєва, Т. Косцов, М. Переверзев, Н. Сабєльнікова, М. Сумінова, Г. Тульчинський та багато інших. Їхні напрацювання охоплюють загальнотеоретичні, історичні, методичні та практичні складники сфери культурно-мистецького управління, що дозволило сформувати грунтовну навчально-методичну базу вищих освітніх установ. Така активність російських науковців була пов'язана не лише з новими часовими викликами, а й затвердженим у 2002-му році Міністерством загальної та професійної освіти РФ державним стандартом освітніх спеціальностей у вищих навчальних закладах «Менеджмент організацій та «Музичний менеджмент» ${ }^{15}$.

Зокрема, одним 3 перших (ще до прийняття Держстандарту в освіті) про менеджмент культури написав у м. Санкт-Петербург Г. Тульчинський, упорядкувавши у 2001-му році навчальний посібник

\footnotetext{
${ }^{14}$ Arts Management Network - State of the arts. URL: https://www.artsmanagement.net/Articles (дата звернення: 01.02.2020).

${ }^{15}$ Корнєєва С. М. Музыкальный менеджмент: учеб. пособие для студентов вузов, обучающихся по специальности «Музыкальный менеджмент» (061166) и специальностям культуры и искусства (050000). Москва: ЮНИТИ-ДАНА, 2006. С. 2.
} 
«Менеджмент у сфері культури» ${ }^{16}$, в якому адаптував світові та вітчизняні економічні технології та механізми сучасним культурним реаліям російської держави. Згодом С. Корнєєва у 2006-му році розробила навчальний посібник з музичного менеджменту для вищих навчальних закладів, котрий забезпечував проведення відповідних дисциплін в освітньому процесі для спеціальностей 3 культури та мистецтва ${ }^{17}$. Посібник присвячений питанням музичного продюсування, розділи якого («Продюсер i управління», «Продюсер i творчість», «Продюсер i економіка», «Продюсер i право») висвітлюють багатогранний комплекс продюсерських функцій, необхідних для успішної реалізації мистецького проєкту. Грунтовне висвітлення питань методології, технологій, етики менеджменту культури і мистецтв у 2010-му році здійснили у посібнику М. Переверзев та Т. Косцов ${ }^{18}$. Їхній доробок призначався для студентів вузів, котрі опановували напрям освіти «Мистецтво та гуманітарні науки», а також для слухачів шкіл шоу-бізнесу, організаторів та управлінців в сфері культури та мистецтв. Наступний навчальний посібник 3 музичного менеджменту М. Воротного вийшов у 2013-му роц ${ }^{19}$ та був присвячений питанням класичного арт-менеджменту в Росії. Матеріал посібника побудований так, щоб читач отримав уявлення про менеджмент як науку та як практичну дисципліну, знав історію його зародження, становлення та розвитку, володів методами організації подій, маркетингу, PR-y, реклами. Необхідний навчальний посібник про управління закладами культури в сучасних умовах у 2014-му році розробила Е. Шекова ${ }^{20}$, в якому розглянула особливості такого менеджменту в умовах переходу на нові форми управління бюджетними установами РФ у зв'язку 3 новими економічними умовами. У 2017-му році вийшла монографія Т. Сумінової ${ }^{21}$, у якій представлена авторська концепція арт-менеджменту як соціокультурного феномену бізнес-реальності ноосферного інформаційного універсуму та як креативно-економічного ресурсу й інструменту реалізації державної політики у сфері культури та мистецтва. Окрім того, у монографії розкрито суть та специфіку фандрейзинга та підприємництва у цій сфері культурної діяльності, а також вперше запропоновано в авторському опрацюванні одну із

\footnotetext{
16 Тульчинский Г.Л. Менеджмент в сфере культуры. Санкт-Петербург : Изд-во «Лань», 2001. 384 с.

${ }^{17}$ Корнєєва С.М. Музыкальный менеджмент: учеб. пособие для студентов вузов, обучающихся по специальности «Музыкальный менеджмент» (061166) и специальностям культуры и искусства (050000). Москва : ЮНИТИ-ДАНА, 2006. 303 с.

18 Переверзев М.П., Косцов Т.В. Менеджмент в сфере культуры и искусства: учеб. пособие. Москва : Инфра-М, 2010. 192 с.

${ }^{19}$ Воротной М.В. Менеджмент музыкального искусства: учеб. пособие. Санкт-Петербург : Изд-во «Лань»; Изд-во «ПЛАНЕТА МУЗЫКИ», 2013. 256 с.

${ }^{20}$ Шекова Е.Л. Управление учреждениями культуры в современных условиях: уч. пособие. СанктПетербург : Изд-во «Лань»; Изд-во «ПЛАНЕТА МУЗЫКИ», 2014. 416 с.

${ }_{21}$ Суминова Т.Н. Арт-менеджмент: реализация государственной политики в сфере культуры и искусства: монография. Москва : Академический проект, 2017. 167 с.
} 
технологій арт-менеджменту - нейролінгвістичне програмування. Одним 3 останніх у 2018-му році вийшов підручник-практикум С. Коленько ${ }^{22}$, метою якого було не лише надання необхідних теоретичних знань, а й розвиток вмінь здобувати необхідну інформацію та навички з навколишнього середовища. Актуальність вищезазначеної проблематики спричинила в сфері економіки появу у 2019-му році дисертації Н.В. Сабєльнікової на тему «Формування механізму управління ефективністю діяльності організацій сфери культури» ${ }^{23}$. Дисертація доводить потенціал культурної сфери в країнах 3 постіндустріальним економічним устроєм, уточнює i розвиває понятійний апарат, доповнює наукові положення щодо вимог ефективного управління, пропонує розробку теоретичних положень механізму управління, відмінних від існуючих раніше розробок в РФ.

Отже, розгляд становлення та розвитку менеджменту як науки окреслює динаміку його соціокультурної прогресії, більшою мірою зумовлену глобалізаційними світовими тенденціями. Проведений ретроспективний огляд матеріалів допомагає виявити, що становлення менеджменту культури як науки відбулось порівняно недавно, від середини XX століття, а процес його розвитку триває й досі, охоплюючи нові сфери, зокрема і музичну.

\section{2. Зародження та становлення менеджменту музичної культури як науки в Україні}

Питання менеджменту культури на теренах України теоретики i практики почали розкривати від початку 1990-х років, фактично цей відлік беремо від появи у 1993-му році першого посібника «Менеджер культури» М. Поплавського (перевиданий у 1996-му році ${ }^{24}$ ). У 1990-му році він захистив докторську дисертацію «Соціально-педагогічні основи організації дозвілля учнівської молоді» ${ }^{25}$ в Ленінградському державному інституті культури ім. Н.К. Крупської (нині - ФДБОУ ВО «СанктПетербурзький державний інститут культури»), ставши на той час першим i єдиним вітчизняним доктором наук в управлінні та економіці соціокультурної сфери. Обійнявши посаду ректора Київського державного інституту культури (від 1993-го року), М. Поплавський лобіює питання соціокультурного менеджменту у науково-видавничій діяльності

\footnotetext{
22 Коленько С. Г. Менеджмент в сфере культуры и искусства: учебник и практикум для академического бакалавриата. Москва: Изд-во «Юрайт», 2018. 370 с.

${ }_{23}^{23}$ Сабельникова Н. В. Формирование механизма управления эффективностью деятельности организаций сферы культуры : автореф. дисс. ... канд. экономических наук. Санкт-Петербург : СанктПетербургский гос. экономический ун-т, 2019. 19 с.

${ }_{24}^{24}$ Поплавський М. Менеджер культури : науковий підручник для студентів вузів культури та мистецтв. КДУКіМ. Київ : Леся, 1996. 416 с.

${ }_{25}$ Поплавський М.М. Социально-педагогические основы организации досуга учащейся молодежи : дисс. ... д-ра пед. Наук : 13.00.05. Ленинград. гос. ин-т культуры им. Н. К. Крупской. Ленинград, 1990. $428 \mathrm{c}$. 
установи $^{26}$, тим самим продукуючи використання його основ у різних сферах культури, в тому числі й музичній. Досвід у сфері шоу-бізнесу ліг в основу напрацювань М. Поплавського, зокрема одна 3 останніх його розвідок описує феномен проєктної діяльності (“crossover point”) та поширення такого явища в сучасній мистецькій практиці ${ }^{27}$.

Від середини 1990-х років у Києві при Національній музичній академії України (НМАУ) ім. П.І. Чайковського був заснований Координаційний центр музичної україністики, очолюваний академіком - засновником Академії мистецтв України, екс-ректором (1968-1974), проректором (1995-1998) НМАУ І. Ляшенком, де започатковувався лекторій зі спецкурсами «Питання економіки i менеджменту в сфері музичної культури». Його метою було надання цілісного уявлення щодо спеціалізованого управління художніми комунікаціями, розроблення науково-методичних матеріалів, налагодження процесу підготовки спеціалістів щодо організації та систематизації музичного життя у вітчизняному соціокультурному середовищі ${ }^{28}$. Згодом, у 1996-му році, під упорядкуванням М. Копиці та І. Котляревського вийшла збірка статей «Питання музичного менеджменту», задекларована як матеріали для обговорення та дискусій ${ }^{29}$, де одними 3 перших публікацій у цій галузі стали праці групи дослідників Координаційного центру Ю. Городецького, Н. Белявіної, Л. Черкашиної та І. Пясковського. У передмові до видання I. Ляшенко зазначає, що пропонована збірка покликана здійснити спробу екстраполяції суто економічних понять на «...доволі специфічні галузі людської діяльності, які мають справу 3 класичною комунікативною тріадою “композитор - виконавець слухач”» ${ }^{30}$. Проте видання було сприйнято неоднозначно українськими музикознавцями через десятиліття та піддалося деякій критиці. Зокрема, професор НМАУ Ю. Чекан, характеризуючи зібрані у збірці матеріали, наголошує на тогочасній неготовності вітчизняних дослідників «...до предметної розмови про менеджмент у сфері культури та мистецтв взагалі і музичний - зокрема» ${ }^{31}$. 3 огляду на критичну думку слід зауважити, що це була все ж перша спроба пошуку та апробації механізмів менеджменту культури часів початку державної незалежності

\footnotetext{
${ }^{26}$ Науково-видавнича діяльність КНУКіМ, 1973-2013 рр. Бібліографічний покажчик / Мін-во культури України, Київ. нац. ун-т культури і мистецтв, Наук. б-ка; упор. О.О. Скаченко, редкол. : М.М. Поплавський, І.С. Бондар, С.Д. Безклубенко [та ін.]. Київ : Вид. центр КНУКіМ, 2014. 284 с.

27 Поплавський М.M. Мистецький проект: дискурс художньої культури початку нового тисячоліття (у точці перетину - crossover point). Вісник НАКККіМ. Київ, 2019. № 1. С. 248-254.

28 Ляшенко І.Ф. Передмова. Питання музичного менеджменту (матеріали для обговорення) / упор. М.Д. Копиця, І.А. Котляревський. Київ : ВАТ «Книжкова друкарня наукової книги», 1996. С. 3.

Питання музичного менеджменту (матеріали для обговорення) / упор. М.Д. Копиця, I.А. Котляревський. Київ : ВАТ «Книжкова друкарня наукової книги», 1996. 152 с.

30 Ляшенко І. Ф. Передмова. Питання музичного менеджменту (матеріали для обговорення) / упор. М.Д. Копиця, І.А. Котляревський. Київ : ВАТ «Книжкова друкарня наукової книги», 1996. С. 3.

1 Чекан Ю. Менеджмент у сфері культури та мистецтв у підготовці сучасного музиканта. Менеджмент соиіокультурної діяльності : колективна монографія / упор. Козаренко О., наук. ред. Пасічник В. Львів : Растр-7, 2018. С. 19.
} 
в умовах пострадянської економіки. Неготовність тогочасних вітчизняних дослідників і практиків до наукового дискурсу можна пояснити найперше невідповідністю тогочасної суспільно-економічної ситуації в державі новим викликам світового прогресу. Зазначимо, що перші поодинокі методико-теоретичні розробки з сучасного економічного управління в Україні з'явились десь в той самий час, що і збірка, а більшою мірою уже на початку XXI-го століття. Окрім того, потрібного накопичення та узагальнення власного практичного досвіду управління мистецькими проектами в тогочасних пострадянських умовах майже не було. Слід додати, що брак фахової літератури 3 дисциплін менеджменту, неспроможність безпосередньо ознайомитись 3 більшістю матеріалів відповідних інституцій економічно розвинених країн також пояснює тогочасні прогалини в напрацюваннях Координаційного центру щодо об'єктивного грунтовного висвітлення теми.

Чергова спроба порушити питання менеджменту культури 1999-го року науковими консультантами Л. Абрамовим та Т. Азаровою здійснилась при Центрі підтримки творчих ініціатив у м. Кіровограді. Навчальнометодичний посібник цих авторів «Менеджмент у сфері культури» 2000-го року ${ }^{32}$ призначався для відповідного тренінгу та вміщував інформацію з теоретичних основ менеджменту, управлінський процес $\mathrm{i}$ галузі культури як об'єкту управління, вимоги до менеджера культури, його стосунків з підлеглими, а також практичні вправи й завдання для самовдосконалення у кінці кожного розділу. Серед базових матеріалів збірці слугували попередня праця як самих авторів, так і напрацювання Західноукраїнського ресурсного центру (ЗУРЦ) у Львові, а також вищезазначений посібник М. Поплавського «Менеджер культури» ${ }^{33}$.

Засадничими для сучасної української культурологічної думки стали дослідження комунікаційних процесів у дисертації В. Шульгіноїі закцентовано увагу на інформаційних засобах як рушійних силах національного розвитку. Водночас значний науковий доробок склали праці О. Берегової, присвячені питанням сучасних комунікаційних технологій та інтегративних процесів в музичній культурі України на межі століть. Фактично, О. Берегова стала першою в Україні музикознавицею, яка висвітлила проблеми арт-менеджменту і музичної комунікації в галузі академічного музичного мистецтва. Запропонована нею схема музичної комунікації доповнює поняття комунікаційної системи менеджменту ${ }^{35}$.

32 Абрамов Л.К., Азарова Т.В. Менеджмент у сфері культури. Тренінг. Кіровоград : ЦПТІ, 2000. $88 \mathrm{c}$.

${ }^{33}$ Там же. С. 86.

${ }^{34}$ Шульгіна В.Д. Музична Україніка: інформаційний і національно-освітній простір : дис. ... д-ра мистецтвознавства. Київ, 2002. 426 с.

35 Обух Л. Концептуалізація поняття «Музичний проект академічного мистецтва». Науковий вісник Наиіональної музичної академії України імені П. І. Чайковського. Київ : НМАУ ім. П. І. Чайковського, 2019. Вип. 125 (2019). С. 91. DOI: https://doi.org/10.31318/2522-4190.2019.125.189050. 
Теорію та практику соціокультурного проєктування в мистецтві під кутом зору культурології та мистецтвознавства описали у підручнику Н. Івановська, В. Шульгіна та О. Яковлєв ${ }^{36}$. Методичне видання акцентує увагу на останніх дослідженнях у цих галузях як вітчизняних, так і світових науковців та митців. Цінним 3 погляду мистецького менеджменту є формулювання авторами основних положень української національної школи, презентація ними парадигми стратегії актуалізації мистецтва в сучасному українському культурному просторі та пропонована модель інноваційного проєкту як синтетичного явища мистецтва XXI століття.

3 початку нового тисячоліття значно активізувались вітчизняні наукові дослідження міждисциплінарного характеру. Зокрема, значний внесок у розвиток менеджменту культури як міждисциплінарної науки зробили дослідження українських науковців, представлені у фаховому журналі «Економіка і менеджмент культури» ${ }^{37}$, засновником і видавцем якого $\epsilon$ Національна академія керівних кадрів культури і мистецтв (м. Київ).

Досить грунтовно мистецтво телекомунікації представлене у монографії А. Скорик ${ }^{38}$, котра розкриває телебачення як аудіовізуальне мистецтво та феномен сучасної медіакультури, що виступає частиною сучасної художньої культури України та її соціокультурного розвитку. Вітчизняний інформаційно-комунікаційний простір в полі культурології та музикознавства став об'єктом досліджень О. Буньківської ${ }^{39}$, Ж. Денисюк ${ }^{40}$, О. Злотника ${ }^{41}$, В. Щербини ${ }^{42}$. Соціальні мережі на вітчизняних теренах стали предметом наукового зацікавлення К. Кислюка ${ }^{43}$. Мережу інтернет як відображення соціальної реальності розглядає Л. Піддубна ${ }^{44}$, котра вбачає iii широке використання у порівняно низьких тарифах. Доволі дешевий доступ до інтернету має і позитивні риси, оскільки сприяє творчій діяльності, командній роботі та дистанційній присутності.

\footnotetext{
${ }^{36}$ Івановська Н.В., Шульгіна В.Д., Яковлєв О.В. Соціокультурне проектування в мистецтві: теорія та практика : підручник. Київ : НАКККіМ, 2018. 196 с.

${ }^{37}$ Економіка і менеджмент культури: науковий журнал. Київ : НАКККіМ, 2015. № 2.117 с.

${ }^{38}$ Скорик А. Мистецтво телекомунікації як феномен сучасної медіакультури: український дискурс : монографія. Львів : Видавець Тетюк Т.В., 2015. 424 с.

39 Буньківська О.В. Інформаційний простір: соціокультурна сутність, стан та проблеми функціонування в Україні : автореф. дис. ... канд. культурології : 26.00.01. Київ : Київський нац. ун-т культури і мистецтв Міністерства культури і туризму України, 2009. 23 с.

40 Денисюк Ж.3. Масова культура і національно-культурна ідентичність в добу глобалізації (вид. 2-е) : монографія. Київ : НАКККіМ, Видавець Олег Філюк, 2017. 224 с.

41 Злотник О. И. Комунікативний простір музичного мистецтва України кінця ХХ - початку XXI століття : автореф. дис. ... канд. мистецтвознавства : 26.00.01. Київ : НАКККіМ, 2019. 24 с.

42 Щербина В. Міжкультурна комунікація у сучасному соціокультурному просторі. Вісник Національного технічного університету України «Київський політехнічний інститут». Політологія. Соиіологія. Право : зб. наук. пр. / Нац. техн. ун-т України «КПІ». Київ : Політехніка, 2013. № 2. С. 70-75.

${ }_{43}$ Кислюк К. Особливості візуальних репрезентацій української культури в соціальних мережах. Вісник НАКККіМ. № 1. Київ, 2019. С. 56-59.

${ }^{44}$ Піддубна Л.В. Мережа інтернет як відображення соціальної реальності. Вісник національного університету «Юридична академія Украӥни імені Ярослава Мудрого». Серія: Філософія, філософія права, політологія, соиіологія. Харків, 2012. КиберЛенинка. URL: https://cyberleninka.ru/article/n/ sotsialna-informatsiya-v-komunikatsiynomu-prostori-suchasnogo-suspilstva (дата звернення: 13.12.2019).
} 
Додатковим джерелом інформації, що допомагає усвідомлювати сучасні підходи до практичного застосування усіх ресурсів менеджменту, стають онлайн-лекції (зокрема, П. Гудімова ${ }^{45}$ та С. Прокоф'євої ${ }^{-46}$ ), розміщені на різноманітних інформаційних платформах. Усвідомлення постійних соціальних змін та суспільних викликів продукує систематичне підвищення кваліфікаційного рівня управлінця будь-якого рівня та будьякої сфери. Така потреба сприяє залученню різноманітних структур. Як приклад, на запрошення регіональної соціальної організації «Тепле місто» (м. Івано-Франківськ) проводяться Live-лекції за участю представників Lviv Business School як фактом затребуваності міждисциплінарного підходу, в тому числі й до організації соціокультурного процесу ${ }^{47}$.

Науковий дискурс щодо означеної проблематики в останнє десятиліття розгорнувся і серед учасників всеукраїнських та міжнародних наукових конференцій та семінарів, частково або цілком присвячених питанням менеджменту в культурно-мистецькому та освітньому просторі, результативність яких засвідчили збірники наукових праць ${ }^{48}$. Зокрема, питання інноваційних технологій у практиці сучасної освіти і культури (технології комунікації в управлінні ВН3, термінологічні аспекти розвитку інтернет-технологій) висвітлювалось на Третій Міжнародній науково-творчій конференції «Культурно-мистецька освіта як складова художнього простору XXI століття» $(2014 \text {, Одеса - Київ - Варшава })^{49}$. На Міжнародній науково-практичній конференції «Культурні домінанти в реаліях XXI століття» (2018, Рівне) теми 3 проблем менеджменту культурної сфери обговорювались майже у всіх секціях. Серед них вирізнялись ті, які були присвячені культурній політиці України в контексті євроінтеграційних процесів, культурно-креативним індустріям, методиці піару закладу вищої освіти, маркетинговим комунікаціям, фестивальному руху, мас-медіа, формуванню корпоративної культури

\footnotetext{
45 Дуже культурний менеджмент. Лекція 1. Як створити культурний проект? Павло Гудімов. Український культурний фонд. YouTube. URL: https://m.youtube.com (дата звернення: 20. 07. 2019).

46 Проектний менеджмент в культурі. Культура і креативність. URL: www.culturepartnership.eu/ ua/publis (дата звернення: 25. 02. 2019).

${ }_{47}$ Обух Л.В. ПР у системі менеджменту академічної музики. Українська культура: минуле, сучасне, иляхи розвитку: наук. зб. Вип. 33 / упор. і наук. ред. В. Г. Виткалов; редкол.: Г.П. Чміль, В.Г. Виткалов, П.Е. Герчанівська та ін. Рівне : РДГУ, 2019. С. 88. DOI: https://doi.org/10.35619/ucpmk.vi33.

48 Діяльність продюсера в культурно-мистецькому просторі XXI століття: традиції, концепції, перспективи : збірник наукових праць (за матеріалами Міжн. наук.-прак. конф., Київ, 20-21 грудня 2012 року) / Відп. за випуск С.М. Садовенко. Київ : НАКККіМ, 2013. 252 с.; Діяльність продюсера в культурно-мистецькому просторі XXI століття: формування громадянського суспільства: зб. наук. праць / Упор., наук. ред., відп. за випуск С.М. Садовенко. Київ : НАКККіМ, 2016. 428 с.; Діяльність продюсера в культурно-мистецькому просторі XXI століття: виклики та концепції сьогодення : зб. наук. праць / Наук. ред., упор. : С. Садовенко. Київ : НАКККіМ, 2018. 137 с.; Культурно-мистецька освіта як складова художнього простору XXI століття : зб. матеріалів Міжн. наук.-творч. конф., Одеса, Київ, Варшава, 30 квітня 2014 р. Київ : НАКККіМ, 2014. 256 с.; Менеджмент соціокультурної діяльності: колективна монографія / упоряд. Козаренко О., наук. ред. Пасічник В. Львів : Растр-7, 2018. 208 c.

49 Програма Третьої Міжнародної науково-творчої конференції «Культурно-мистецька освіта як складова художнього простору XXI століття» 29-30 квітня 2014 р. Одеса - Київ - Варшава. Київ : НАКККіМ, 2014. $24 \mathrm{c}$.
} 
освітнього закладу художньо-естетичного профілю, особливостям підготовки менеджерів музичної культури у вищих навчальних закладах, мистецькому проєкту як феномену XXI-го століття, соціокультурним концепціям управління в менеджменті, благодійництву в культурі, децентралізації культурної сфери ${ }^{50}$. До конференцій, цілком присвячених питанням менеджменту культури, зараховуємо Міжнародну наукову конференцію «Менеджмент культури та культурний менеджмент: динаміка взаємодії» (2017, Львів), щорічні Міжнародні науково-практичні конференції «Діяльність продюсера в культурно-мистецькому просторі XXI століття» (2006-2019, Київ), зініційовані та організовані НАКККіМ, метою яких, за визначенням ректора В. Чернеця, $\epsilon$ «...поглиблення ефективності діяльності продюсера в культурно-мистецькому просторі, зокрема, в контексті відповідальності продюсера за формування цілісного громадянського суспільства, пошук і знаходження відповідей на виклики сьогодення, створення нових концепцій та постійне відтворення єдиного смислового поля культури» ${ }^{51}$. Серед тематичних наукових конференцій, ініційованих та проведених Київським національним університетом культури і мистецтв, вирізняються: I Всеукраїнська науково-практична конференція «Потенціал культурних індустрій України в контексті світових тенденцій (2014), Міжнародні науково-практичні конференції «Інформаційні технології в культурі, мистецтві, освіті, науці, економіці та бізнесі» (2016-2017, 2020) та «Креативні технології, підприємництво i менеджмент в організації соціокультурної сфери XXI століття» (20172018), Всеукраїнський науково-методичний семінар «Формування сучасної парадигми менеджмент-освіти у соціокультурній сфері» (2017), Всеукраїнська науково-практична конференція «Філософія подієвої культури: теорія та практика» $(2020)^{52}$.

Загалом тематика та проблематика вищезазначених конференцій виявляє позитивну динаміку актуалізації питань менеджменту на початку нового тисячоліття в українських науково-теоретичних студіях. Конференції цікаві та корисні тим, що об'єднали різні галузі знань (культурологію, економіку, філософію, соціологію, мистецтвознавство тощо), бо, за визначенням О. Козаренка, лише в синергії різних методологій виникає можливість «осягнути шляхи екзистенції культури (а за нею - i людства) в сучасних вкрай ускладнених і загрозливих умовах виживання» 53 .

\footnotetext{
${ }^{50}$ Культурні домінанти в реаліях XXI століття: програма XIV Міжнародної науково-практичної конференції: 15-16 листопада 2018 року / укл. : Виткалов С.В. Рівне : РДГУ, 2018. 42 с.

51 Діяльність продюсера в культурно-мистецькому просторі XXI століття: формування громадянського суспільства: зб. наук. праць / Упор., наук. ред., відп. за випуск С.М. Садовенко. Київ : НАКККіМ, 2016. C. 3.

${ }^{52}$ Наукові конференції. Сайт Київського наиіонального університету культури і мистецтв. URL: http://knukim.edu.ua/naukova-robota/naukovi-konferentsiyi/19686/ (дата звернення: 08.07.2020).

${ }^{53}$ Козаренко О. Вступ. Менеджмент соиіокультурної діяльності: колективна монографія / упоряд. Козаренко О., наук. ред. Пасічник В. Львів : Растр-7, 2018. С. 5.
} 
В останні роки все частіше 3'являються науково-популярні розвідки про успішні мистецькі проекти (зокрема, публікації Г. Карась ${ }^{54}$ в спеціалізованому журналі «Музика»), котрі констатують доцільність та апелюють до використання сучасних бізнес-прийомів і у сфері популяризації академічної музики.

Отже, менеджмент музичної культури на теренах України - порівняно нова міждисциплінарна наукова проблема, вирішенням якої вітчизняні науковці почали займатися наприкінці XX - початку XXI століть. Якщо від початку становлення державної незалежності це були поодинокі спроби, то з кожним наступним десятиліттям таких праць ставало дедалі більше, а їхня тематика - різноманітніша. Опрацьовані матеріали засвідчують актуальність питання в контексті пошуку нових напрямів розвитку та переосмислення ціннісних установ в культурології та мистецтвознавстві.

\section{ВИСНОВКИ}

На межі XX-XXI століть, коли глибинні соціокультурні зміни у світовому масштабі трансформують будь-які процеси людської діяльності, менеджмент має місце практично в усіх сферах функціонування суспільства, зокрема і в культурі. Як універсальна наука про управління, створена науково-технічним прогресом у XX столітті, на початку XXI-го менеджмент виявився продуктом культурного розвитку суспільства, що водночас виступає передумовою формування нових соціокультурних можливостей.

Комплексне дослідження історичних процесів становлення та розвитку менеджменту музичної культури як наукової дисципліни дозволяе виявити загальні світові та вітчизняні тенденції, як-от: зміна поглядів на роль культурної сфери в економіці, адаптивність соціокультурних процесів економічним стандартам, динамічність розвитку науковотеоретичної думки.

Загальний огляд літератури про становлення та розвиток менеджменту культури загалом і музичної зокрема засвідчує актуальність порушеної проблематики серед українських культурологічних та музикознавчих розвідок. Адже якщо у світовій науковій спільноті така проблема достатньо розроблена, то серед вітчизняного музикознавства й досі бракує системних напрацювань.

Як виявлено, окремі питання менеджменту культури розкривають поодинокі наукові дисертації та монографії, збірники статей, науковопопулярні публікації, тези доповідей науково-практичних конференцій, подкасти, лекції тощо. Проте для української науково-теоретичної

\footnotetext{
${ }^{54}$ Карась Г. У полоні мистецької пісні. Музика. Ч. 5-6. Київ, 2016. С. 39-42; Проект «рина Ключковська. Фантазії» (вокальна музика А. Кос-Анатольського та О. Козаренка). Музика. Ч. 3-4. Київ, 2019. С. 46-50. 
думки й досі залишаються відкритими низка питань менеджменту музичного мистецтва в тих соціокультурних умовах, в яких перебуває сучасна держава.

\begin{abstract}
АНОТАЦІЯ
Розвідка присвячена становленню та розвитку менеджменту музичної культури як науки в світовому соціокультурному просторі, так і на теренах української держави на зламі століть.

Комплексний огляд зібраних матеріалів дозволяє виявити ступінь дослідження проблеми у світовій і вітчизняній науково-теоретичних думках та виокремити загальні тенденції цього процесу.

Досліджено, що на початку XXI століття менеджмент музичної культури постає як самостійний культурологічний напрям. Сутнісна специфіка цього напряму полягає в синтезі напрацювань із царини низки наук (економіки, культурології, соціології, мистецтвознавства). Такий міждисциплінарний підхід стає найхарактернішою рисою, що дозволяє впроваджувати та розробляти нові концепції щодо управління як передумови успішного функціонування різноманітними культурними сферами як, наприклад, музичне мистецтво.
\end{abstract}

\title{
ЛІТЕРАТУРА
}

1. Абрамов Л.К., Азарова Т.В. Менеджмент у сфері культури. Тренінг. Кіровоград : ЦПТІ, 2000. 88 с.

2. Буньківська О.В. Інформаційний простір: соціокультурна сутність, стан та проблеми функціонування в Україні : автореф. дис. ... канд. культурології : 26.00.01. Київ : Київський нац. ун-т культури і мистецтв Міністерства культури і туризму України, 2009. 23 с.

3. Денисюк Ж.3. Масова культура i національно-культурна ідентичність в добу глобалізації (вид. 2-е) : монографія. Київ : НАКККіМ, Видавець Олег Філюк, 2017. 224 с.

4. Злотник О. Й. Комунікативний простір музичного мистецтва України кінця XX - початку XXI століття : автореферат дис. ... кандидата мистецтвознавства за спеціальністю 26.00.01 - теорія та історія культури. Київ : НАКККіМ, 2019. 24 с.

5. Діяльність продюсера в культурно-мистецькому просторі XXI століття: виклики та концепції сьогодення : зб. наук. праць / Наук. ред., упор. : С. Садовенко. Київ : НАКККіМ, 2018. 137 с.

6. Діяльність продюсера в культурно-мистецькому просторі XXI століття: традиції, концепції, перспективи : зб. наук. праць (за матеріалами Міжн. Наук.-прак. конф., Київ, 20-21 грудня 2012 року) / Відп. за випуск С. М. Садовенко. Київ : НАКККіМ, 2013. 252 с. 
7. Діяльність продюсера в культурно-мистецькому просторі XXI століття: формування громадянського суспільства : зб. наук. праць / Упор., наук. ред., відп. за випуск С.М. Садовенко. Київ : НАКККіМ, 2016. $428 \mathrm{c}$.

8. Дуже культурний менеджмент. Лекція 1. Як створити культурний проект? Павло Гудімов. Український культурний фонд. YouTube. URL: https://m.youtube.com (дата звернення: 20. 07. 2019).

9. Економіка i менеджмент культури: науковий журнал. Київ : НАКККіМ, 2015. № 2.117 c.

10. Івановська Н.В., Шульгіна В.Д., Яковлєв О.В. Соціокультурне проектування в мистецтві: теорія та практика : підручник. Київ : НАКККіМ, 2018. $196 \mathrm{c}$.

12. Карась Г. У полоні мистецької пісні. Музика. Ч. 5-6. Київ, 2016. C. 39-42.

13. Карась Г. Проект «Ірина Ключковська. Фантазії» (вокальна музика А. Кос-Анатольського та О. Козаренка). Музика. Ч. 3-4. Київ, 2019. C. $46-50$.

14. Кислюк К. Особливості візуальних репрезентацій української культури в соціальних мережах. Вісник НАКККіМ. № 1. Київ, 2019. С. $56-59$.

15. Козаренко О. Вступ. Менеджмент соиіокультурної діяльності: колективна монографія / упоряд. Козаренко О., наук. ред. Пасічник В. Львів : Растр-7, 2018. С. 5-6.

16. Коленько С.Г. Менеджмент в сфере культуры и искусства: учебник и практикум для академического бакалавриата. Москва : Изд-во «Юрайт», 2018. 370 с.

17. Культурні домінанти в реаліях XXI століття: програма XIV Міжнародної науково-практичної конференції: 15-16 листопада 2018 року / укл.: Виткалов С.В. Рівне : РДГУ, 2018. 42 с.

18. Культурно-мистецька освіта як складова художнього простору XXI століття : зб. матеріалів Міжн. наук.-творч. конф., Одеса, Київ, Варшава, 30 квітня 2014 р. Київ : НАКККіМ, 2014. 256 с.

19. Ляшенко І.Ф. Передмова. Питання музичного менеджменту (матеріали для обговорення) / упор. М.Д. Копиця, І.А. Котляревський. Київ : ВАТ «Книжкова друкарня наукової книги», 1996. С. 3.

20. Менеджмент соціокультурної діяльності : колективна монографія / упоряд. Козаренко О., наук. ред. Пасічник В. Львів : Растр-7, 2018. 208 с.

21. Наукові конференції. Сайт Київького національного університету культури і мистеитв. URL: http://knukim.edu.ua/naukovarobota/naukovi-konferentsiyi/19686/ (дата звернення: 08.07.2020).

22. Науково-видавнича діяльність КНУКіМ, 1973-2013рр. Бібліографічний покажчик / Мін-во культури України, Київ. нац. ун-т 
культури і мистецтв, Наук. б-ка; упор. О.О. Скаченко, редкол.: М.М. Поплавський, І.С. Бондар, С.Д. Безклубенко [та ін.]. Київ : Вид. центр КНУКіМ, 2014. 284 с.

23. Обух Л.В. Концептуалізація поняття «Музичний проект академічного мистецтва». Науковий вісник Національної музичної академії України імені П. І. Чайковського. Київ : НМАУ ім. П.І. Чайковського, 2019. Вип. 125 (2019). С. 89-103. DOI: https://doi.org/10.31318/ 2522-4190.2019.125.189050.

24. Обух Л.В. PR у системі менеджменту академічної музики. Украӥнська культура: минуле, сучасне, иляхи розвитку: наук. зб. Вип. 33 / упор. і наук. ред. В.Г. Виткалов; редкол. : Г.П. Чміль, В.Г. Виткалов, П.Е. Герчанівська та інші. Рівне : РДГУ, 2019. С. 84-90. DOI: https://doi.org/10.35619/ucpmk.vi33.

25. Піддубна Л.В. Мережа інтернет як відображення соціальної реальності. Вісник національного університету «Юридична академія України імені Ярослава Мудрого». Серія: Філософія, філософія права, політологія, соиіологія. Харків, 2012. URL: https://cyberleninka.ru/article/ $\mathrm{n}$ /sotsialna-informatsiya-v-komunikatsiynomu-prostori-suchasnogo-suspilstva (дата звернення: 13.12.2019.).

26. Питання музичного менеджменту (матеріали для обговорення)/ упор. М.Д. Копиця, I.А. Котляревський. Київ : ВАТ «Книжкова друкарня наукової книги», 1996. $152 \mathrm{c.}$

27. Поплавський М. Менеджер культури: науковий підручник для студентів вузів культури та мистецтв. КДУКіМ. Київ : Леся, 1996. 416 с.

28. Поплавський M.M. Мистецький проект: дискурс художньої культури початку нового тисячоліття (у точці перетину - crossover point). Вісник НАКККіМ. Київ, 2019. № 1. С. 248-254.

29. Поплавський М.М. Социально-педагогические основы организации досуга учащейся молодежи : дисс. ... д-ра пед. наук : 13.00.05. Ленинград. гос. ин-т культури им. Н.К. Крупской. Ленинград, 1990. 428 с.

30. Програма Третьої Міжнародної науково-творчої конференції «Культурно-мистецька освіта як складова художнього простору XXI століття» 29-30 квітня 2014 р. Одеса-Київ-Варшава. Київ : НАКККіМ, 2014. $24 \mathrm{c}$.

31. Проектний менеджмент в культурі. Культура і креативність. URL: www.culturepartnership.eu/ua/publis (дата звернення: 25. 02. 2019).

32. Сабельникова Н.В. Формирование механизма управления эффективностью деятельности организаций сферы культуры : автореф. дисс. ... канд. эконом. наук. Санкт-Петербург : Санкт-Петербургский гос. эконом. ун-т, 2019. 19 с. 
33. Скорик А. Мистецтво телекомунікації як феномен сучасної медіакультури: український дискурс: монографія. Львів : Видавець Тетюк Т. В., 2015. 424 с.

34. Чекан Ю. Менеджмент у сфері культури та мистецтв у підготовці сучасного музиканта. Менеджмент соціокультурної діяльності: колективна монографія / упор. Козаренко О., наук. ред. Пасічник В. Львів : Растр-7, 2018. С. 16-24.

35. Шульгіна В.Д. Музична Україніка: інформаційний і національноосвітній простір : дис. ... д-ра мистецтвознавства. Київ, 2002. 426 с.

36. Щербина В. Міжкультурна комунікація у сучасному соціокультурному просторі. Вісник Національного технічного університету Украйни «Київський політехнічний інститут». Політологія. Соџіологія. Право.: зб. наук. пр. / Нац. техн. ун-т України «КПІ». Київ : Політехніка, 2013. № 2. C. 70-75.

Information about author: Obukh L. V., $\mathrm{PhD}$ of Arts, Doctoral Student, Senior Lecturer Educational and Scientific Institute of Arts of Vasyl Stefanyk Precarpathian National University 57, Shevchenko str., Ivano-Frankivsk, 76018, Ukraine 